\title{
Evaluation of Translation and Interpretation of the Dangme Bible
}

\author{
Jonathan E.T. Kuwornu-Adjaottor 1 \\ ${ }^{1}$ Department of Religious Studies, Kwame Nkrumah University of Science and Technology, Kumasi Ghana.
}

\begin{abstract}
A critical reading of the Dangme translation of the Bible revealed that there are translation problems of some texts that affect the understanding and application of such texts in the religio-cultural context of Dangme Bible readers. Using the mixed method of research and the mother tongue biblical hermeneutics approach, the author sought to research some phrases of three of such problematic texts: Matt 6:12; Mark 1:12; Luke 24:25. The findings are that among Dangme Bible readers, $k \varepsilon$ ke (Grk. afes, forgive, let go) in Matt 6:12

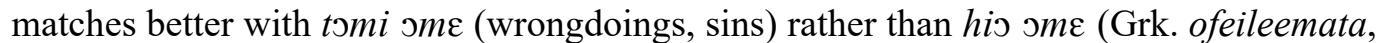
debts); in Mark 1:12, ha $n \varepsilon$ e ho (permitted him to go) is a better rendition of the Greek ekballoo (threw out/cast out); in Luke 24:25, Oo nye jucmi he jo, (your mind has become cold) tones down the insult in anoeetoi translated as kuasiahi. The author's translation of the texts would go a long way in helping Dangme Bible readers understand the said texts in context. The paper has thus, added Dangme translations and interpretations of Matt 6:12, Mark 1:12 and Luke 24:25 to the existing translations and interpretations of the texts.
\end{abstract}

\section{Correspondence:}

Jonathan E.T. Kuwornu-Adjaottor Email: jkadjaottor@gmail.com

\section{Manuscript}

Received 24th November 2020, Accepted 10th December 2020, Published online 18th December 2020.

Keywords: Dangme Bible, translation, interpretation, mother tongue

(C) 2020 The Author. Published and Maintained by Noyam Publishers.

This is an open access article under the CCBY license (http://creativecommons.org/licenses/by/4.0/)

\section{INTRODUCTION ${ }^{1}$}

Bible translation from the Source Languages (SL) to a Receptor Language (RL) is a theological activity in that through translation God speaks to people in their mother tongue. By mother tongue, the author means the language into which one is born and nurtured. Mother tongue is a linguistic category that expresses origin, competence, and function. ${ }^{2}$ It expresses the idea that the initial communication skills of a child are acquired from the mother; therefore, the language of the mother would be the primary language that the child would learn. Thus, Dangme is a mother tongue; Ga is also a mother tongue.

\section{Mother tongue in theological discussions}

Below are views expressed by some African translation theologians.

Lamin Sanneh: The fact that Scripture was translated from Jewish culture - Aramaic and Hebrew, into the Gentile culture - Greek, is enough point to establish a pattern for translation, appropriation, and assimilation of languages and cultures. ${ }^{3}$ To him, the "Success of Christianity will call for education that will bring us new ways of viewing the world, commencing a process of revitalization that reaches into both the personal and cultural spheres."4

Kwame Bediako: The deep mother-tongue roots of large portions of African Christianity is an opportunity for shaping

\footnotetext{
This paper was intitially presented by the author on the occasion of the 20th Anniversary Celebration of the Dangme Bible Launch on Sunday 22nd November 2020 at Mount Zion Presbyterian Church, Dodowa Ghana. It was presented with the title "Journey of the Dangme Bible."

Raymond F. Collins. I \& II Timothy and Titus. The New Testament Library (Louisville: Westminster John Knox Press, 2002).

Lamin Sanneh, Translating the Message: The Missionary Impact on Culture (New York: Orbis Books, 2004$), 1$.

4 Lamin Sanneh, "Gospel and Culture: Ramifying Effects of Scripture Translation.” In: Stine, P.C. ed., Bible Translation and the Spread of the Church, The Last 200 Years (Leiden: Brill. 1990), 52-53.
} 
Christian theological discourse in Africa. ${ }^{5}$ The development of theological concern and the formulation of theological questions are closely linked with the identity of which the mother tongue is the basis. He is of the view that "God speaks into the African context in African idioms, and ... it is through hearing in African mother tongues "the great things God has done (Acts 2:11)', that African theology emerges to edify not only the African church but the church worldwide." He opines that, "The mother-tongue is a repository of indigenous wisdom, knowledge, insight, science, theology and philosophy. It is in the mother-tongue that one thinks and dreams, before translating one's thoughts to other languages."

The views of the scholars mentioned above suggest the Biblical hermeneutics has a cultural dimension and as such it must include exegesis that reflects a dynamic encounter between Christian and traditional African worldviews, both of which continue to exert a powerful influence on communities. When the Bible enters a culture it should put on the garment of that culture. Appropriate cultural categories should be used to explain biblical truths in a context.

John David Kwamena Ekem: He conducted a historical case study of the translation of the Bible into four dominant languages - Gā, Twi (Akuapem and Asante), Mfantse and Ewe of the Gold Coast, now Ghana. ${ }^{8}$ Regarding the Gā Bible, Ekem acknowledges pioneers like Rev. W. A. Hanson, and focuses on Johannes Zimmermann and his team of national translators who worked together to ensure the translation of the Bible into Gā. In discussing the history of the translation of the Bible into the Akan dialects of Akuapem-Twi and Asante-Twi, Ekem pays particular attention to the work of the Basel Missionaries, especially, Johann Christaller and indigenes like David Asante, Clement Anderson Akrofi and C.A. Denteh. He highlights the development of the Akan language and the politics that went with it. In discussing the translation of the Bible into Mfantse, Ekem says that, unlike the Ga, Akuapem-Twi and Asante-Twi translations, the Mfantse Bible is unique in that its translation was initiated by indigenes. He discusses in detail, the roles of Revs Andrew Parker, J O. Hammond, and Gabriel Acquah. With regards to the translation of the Bible into the Ewe language, Ekem highlights the critical contribution between translators from the Northern German Society (popularly referred to as the Bremen Mission) and their indigenous counterparts in a rich biographical and historical detail. ${ }^{9}$

David Nii Anum Kpobi: Kpobi joins the discussion on Bible translation in Ghana in his book, Entrusted with the Word: A History of the Bible Society of Ghana, 1965-2015 that traces the historical development of the Bible Society of Ghana and its development from the global Bible Societies. ${ }^{10}$ Though Kpobi's work is historical, he raises issues that hinge on the lack of Bible helps such as Study Bibles, commentaries and dictionaries in Ghanaian mother tongues. He says that engaging in these projects requires adaptation of existing works and translation and interpretation from one language to another.

\section{The Dangme Bible Translation Project:}

The Dangme Bible translation project started in the early 1960s with the New Testament which was published as Somi $\mathrm{He} \hat{\mathbf{o}}$ and launched in 1977and the Kpong Presbyterian Church. The translation of the Old Testament into Dangme started in 1982 and was completed in 1996. The New Testament was revised and added to the Old Testament. The Dangme Bible, Ngmami Klouklou o was published in 1999 by the Bible Society of Ghana and the United Bible Societies (BSG/ UBS) and launched in 2000 at the Lasi Park, Odumase-Krobo in the Eastern Region. ${ }^{11}$

Personal communication with E. D. Leiku and G. D. Kitcher (now G. D. Kitcher-Asare), the two survivors of the Dangme Bible translation team revealed that C. W. Doku, J. M. T. Dosu, E. Populampo, S. T Akornor, E. D. Leiku and G. D Kitcher translated the Bible into Dangme. The Bible Translation Consultant (BTC) at the time was Rev. Prof. G. Ansre, a linguist. He supervised more than two-thirds of the Dangme Bible translation project. The Dangme Bible was however launched when Rev. Dr. J. D. K. Ekem (now Very Rev. Professor Ekem) was the Translation Consultant of the BSG, after supervising some portions of the Dangme translation and the proofreading.

The Dangme Bible translation team did not use one specific source during the translation. They relied on sources such as Bible Helps and Translation Guides, different English versions of the Bible - KJV, RSV, NIV, TEV $(G N B)$; and some earlier Ghanaian mother-tongue translations - Gā, Ewe, Mfantse, Akuapem-Twi and Asante-Twi.

\footnotetext{
Kwame Bediako, Christianity in Africa: The Renewal of Non-Western Religion (Maryknoll, New York: Orbis Books, 1995/1999).

Kwame Bediako, Jesus in Africa: The Gospel in African History and Experience (Akropong: Editions Clé and Regnum Africa, 2000$)$, vii.

$6 \quad$ Kwame Bediako. Religion, Culture and Language: An Appreciation of the Intellectual Legacy of Dr. J.B. Danquah - J. B. Danquah Memorial Lectures, Series 37, February 2004 (Accra: Ghana Academy of Arts \& Sciences 2006), 37.

John D. K. Ekem, Early Scriptures of the Gold Coast (Ghana): The Historical, Linguistic, and Theological Settings of the Gā, Twi, Mfantse, and Ewe Bibles (Rome/Manchester: Edizioni di Storia Eletteratura/St. Jerome, 2011).

8 John D. K.Ekem, Priesthood in Context: A Study of Priesthood in Some Christian and Primal Communities of Ghana and its Relevance for Mother-Tongue Biblical Interpretation (Accra: SonLife Press, 2008).

9 David N.A Kpobi, Entrusted with the Word: A History of the Bible Society of Ghana, 1965-2015 (Accra: Heritage Publications 2015).

11 Face-to-face interview with E. D. Leiku, January 6, 2011 at KNUST, Kumasi; telephone interview with G. D. Kitcher-Asare, January 7, 2012.
} 
The team also went to indigenous Dangme -speaking communities and researched into words that posed hermeneutical challenges to them. ${ }^{12}$

Some of the challenges the Dangme Bible Translation Team faced were that, along the line, some of the books that were translated and were sent for review could not be traced; they got missing, and they had to be translated again. This may be due to poor record keeping on the part of the translation team. Also, some of the reviewers did not return their scripts on time. ${ }^{13}$

Kpobi gives some information on the Dangme Bible in his book, Entrusted with the Word. ${ }^{14} 15$ The Dangme Bible was recorded on cassettes in 2006 as part of the Faith Comes By Hearing (FCBH) project, to facilitate the reading and discussion of the Dangme Bible in churches and communities. ${ }^{15} 16$ He illustrates this with a picture of Dangme people in a town procession at Kasseh, Ada "expressing joy because they can now listen to the Word of God in their own mother tongue, Dangme." 1617 He indicates that at a special Bible Reading Marathon to commemorate the Bicentenary of the Bible Society worldwide held at the Ridge Church, Accra in 2004, the Dangme Bible was also read ${ }^{17} 18$

\section{EVALUATION OF TRANSLATION AND INTERPRETATION OF THE DANGME BIBLE Problems with the Dangme Translation of the Bible}

A paragraph of the Nya TsJomi (Preface) of the Ngmami Klouklou ग, The Dangme Bible reads Ngmami Klouklou

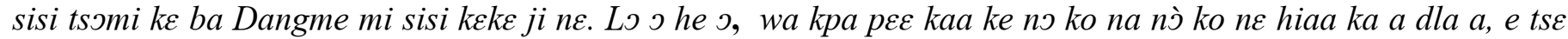
Ghana Biblo Kuи э tue se nge he, kone a tsu he ni (The translation of the Bible into Dangme is just the beginning. Therefore, we plead that if anyone sees something that needs to be corrected, he or she must bring it to the notice of the Bible Society of Ghana, so that it could be corrected).

This statement set the author thinking and caused him to read the Dangme Bible with critical eyes. He found out that, there are translation and cultural issues facing readers of the Bible. The way some Hebrew and Greek terms, concepts, and phrases have been translated in the Dangme Bible poses a hermeneutical challenge to readers.

\section{METHODOLOGY}

The study used the mixed method of research and the mother tongue biblical hermeneutics ${ }^{18} 19$ approach. Opened ended questions and questionnaire were used in surveying the eight Dangme-speaking areas in the Greater Accra and Eastern regions of Ghana in July 2009. These areas are Ada, Ningo, Kpone, Prampram, Shai, Osudoku, Yilo-Krobo, ManyaKrobo. With the help of eight (8) research assistants, the researcher sent out questionnaires to 1000 respondents from various churches in the eight Dangme speaking areas, to find out whether readers of the Dangme Bible have noticed some translation problems that were not helping them to understand the message of a text. Five hundred and sixty-five (565) people responded to the questionnaire. Majority of the four hundred and thirty-five people who declined response to the questionnaire said the Bible is absolute and they were afraid to add to or subtract from Scripture (Deut 4:2; Rev 22:18).

Table 1: Respondents from the Eight Dangme-speaking Areas

\begin{tabular}{|l|l|l|}
\hline Dangme-speaking Area & Number of Questionnaires Distributed & Number of Respondents (\%) \\
\hline Ada & 150 & $119(21.1 \%)$ \\
\hline Ningo & 100 & $12(2.1 \%)$ \\
\hline Kpone & 100 & $24(4.2 \%)$ \\
\hline Prampram & 100 & $12(2.1 \%)$ \\
\hline Shai & 150 & $76(13.5 \%)$ \\
\hline Osudoku & 100 & $84(14.9 \%)$ \\
\hline Manya-Krobo & 150 & $98(17.3 \%)$ \\
\hline Yilo-Krobo & 150 & $140(24.8 \%)$ \\
\hline Total & 1000 & $565(100 \%)$ \\
\hline
\end{tabular}

\footnotetext{
12 Telephone interview with Kticher-Asare.

Telephone interview with Kitcher-Asare.

Kpobi, Entrusted with the Word, 75, 76. 249.

Kpobi, Entrusted with the Word, 75, 76. 249.

Kpobi, Entrusted with the Word, 75, 76. 249.

Kpobi, Entrusted with the Word, 83-84.

8 Jonathan E. T. Kuwornu-Adjaottor, Doing Biblical Studies using the Mother-tongue Approach. All Nations University Journal of Applied Thought (ANUJAT) 1 no. $1(2012): 55-80$.
} 
Source: Field Data, 2009

Table 2: Translation Problems in the Dangme Bible

\begin{tabular}{|l|l|l|l|l|}
\hline Tribe & Yes & No & Cannot Identify Translation Problem & Total \\
\hline Ada & 93 & 6 & 20 & 119 \\
\hline Ningo & 8 & 3 & 2 & 12 \\
\hline Kpone & 7 & 2 & 15 & 24 \\
\hline Prampram & 9 & 1 & 3 & 12 \\
\hline Shai & 53 & 18 & 4 & 76 \\
\hline Osudoku & 66 & 10 & 7 & 84 \\
\hline Manya-Krobo & 75 & 17 & 6 & 98 \\
\hline Yilo-Krobo & 101 & 27 & 12 & 140 \\
\hline Total & $412(72.9 \%)$ & $84(14.9 \%)$ & $69(12.2 \%)$ & $565(100.0 \%)$ \\
\hline
\end{tabular}

Source: Field Data, 2009

- $412(72.9 \%)$ identified some translation problems in the Dangme Bible which sometimes posed problems in the understanding of certain verses.

- $84(14.9 \%)$ did not identify translation problems in the Dangme Bible;

- $69(12.2 \%)$ could not identify translation problems in the Dangme Bible.

The majority of the number who said they could identify translation problems in the Dangme Bible makes this an issue that called for research.

\section{Issues with some identified texts are as follows:}

1. The translation of sukeen mian, the tree that Jesus cursed in Matthew 21:18-19 as ngmokstso in the Dangme Bible. Ngmokstso is the plant commonly known as milk bush; it is used for fencing; it is not edible; its fruits are poisonous. In the Greek translation, Jesus did not curse a tree with inedible fruits.

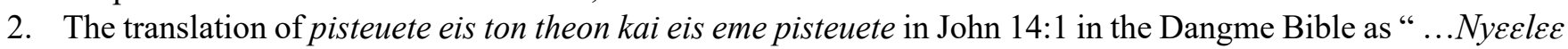
nye he Mawunyes ye; ne imi hunye he mi nyes ye." [As for you, believe in God; and believe also in me]. The first pisteuete in the text can be seen from two perspectives: as an affirmation or a command. Is the pisteuete eis ton theon a command or an affirmation of the belief of the disciples' in God? How should this text be translated against the background that the Dangme knew Mawu (God) before Christ was introduced to them?

3. The translation of theoi "gods" as Mawuэme (the Gods) in Acts 14:11b, when in actual sense it means jemawoวme [the lesser gods]. Translating the word into the Dangme, and starting it with a capital "M" means that the lesser goods are equal in attribute to Mawu, the Almighty God.The translation of xenoon daimonioon "foreign gods" as mawuhi in Acts 17:18b, instead of jemaws hi. Among the Dangme there is only one Supreme Being called Mawu; there are gods known as jemawo hi, which are local but may be foreign to the communities

4. The translation of hoti aneer estinkephalee tees yunaikos in Ephesians 5:22-23 as "...Ejakaa hunos nge e yoэns he wami..." [Because the husband has authority over his wife...]. Is it that a husband is the leader in his family or he has authority over his wife? How should this verse be interpreted to bring peace and understanding between husbands and wives in Dangme Bible reading communities?

5. The translation of mias gunaikos andra in 1 Timothy 3:1-2a as “...Asafonyadalos, sékó hi e he. É hi yo kake. The person who wants to take care of God's church should be above reproach: the husband of one wife]. The basic problem with the Dangme translation is that $E$ is a pronoun for all genders - he, she, it. But the difficulty here is that in the phrase, é hi yo kake [should have one wife], the é is masculine; meaning only men can become leaders in a church. Further, such men must be married. But today we have Dangme men and women who are pastors and church leaders; some are not married. An exegetical study of the text reveals that the meaning of that text is that a person who wants to lead the church - regardless of sex - should be without reproach.

6. The translation of "nephew" (NIV) in Genesis 12:5; 14:12-16 as wofase, which is an Akan word. It seems the Dangme do not have a word for nephew.

7. The translation of the "Almighty God" as Yawe in Psalm 23:1. This translation seems to suggest that the Dangme do not have a name for God. Further, the way Dangme Bible pronounces Yawe is appalling. God's name is pronounced YaweE. The translators have adopted the ' $h$ ' sound at the end of the English transliteration Yaweh, making it sound like a long vowel; and that confuses the pronunciation of the name by Dangme Bible 
readers. The double â at the end of pronunciation is something that needs to be corrected. The translators should render the name of God as follows: Yawz. This will agree with the Hebrew pronunciation and the English transliteration.

Three of the identified texts with problems - Matthew 6:12, Mark 1:12, Luke 24:25, generated a lot of questions and discussions among Dangme Bible readers during the field research. These were studied using the mother tongue biblical hermeneutics methodology. ${ }^{19}$

1. Ngэว wa tэmi эme ke pa wว... (Lend us our wrong-doings...) (Matt. 6:12). Pa (lend) in Dangme among other things is also an economic term. With its usage in the Lord's Prayer in reference to forgiveness, the question one might ask is, does God "lend" us our sins or he "forgives" us our sins?

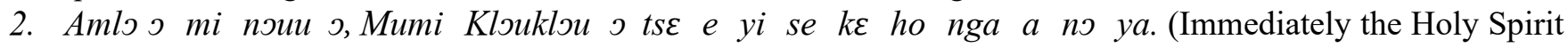
pushed him by the head into the wilderness) (Mk. 1:12).

3. Among the Dangme none a tse e yi se (the one pushed by the head) is a "bad boy/girl" who is reluctant to do something but have to be forced. The phrase also implies that it was not yet time for Jesus to be tempted, but the Spirit forced him to go to the wilderness to face Satan. The critical question: Does the Spirit force one to take an action?

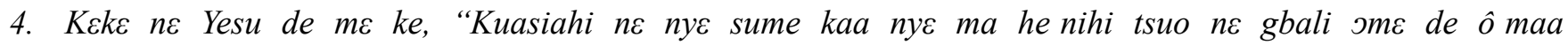
ye!" (Then Jesus said to them, "Fools; you do not want to believe all that the prophets had said") (Lk. 24:25). The translation of anoeetoi as kuasiahi "fools" has religio-cultural implications for Dangme speaking people. Among the Dangme, kuasia is a ritual insult. The traditional priest does not use it on the living because it has repercussions. The translators have put kuasiahi in the mouth of Jesus who is divine, and this might lower the reverence Dangme Christians and Bible readers have for Jesus.

\section{Theoretical Framework}

John David Kwamina Ekem

"The varied mother tongues of Africa have a lot to offer by way of biblical interpretation in Ghanaian/African languages as a viable material for interpretation, study Bibles and commentaries." 20 "Mother-tongue biblical hermeneutics, is a discipline devoted to the interpretation and reinterpretation of biblical texts in languages considered by speakers as their first languages into which they were born." ${ }^{21}$

\section{Philosophy}

The philosophy underpinning the study is Deconstruction proposed by Jacques Derrida. Deconstruction is a form of hermeneutics of interpreting a text, with the aim of not dismantling it, but remodeling it. According to this philosophy, the meaning is relative to culture and situation; the truth is conditioned by one's perspective. Meaning is ultimately untransferable between writer and reader. ${ }^{22}$

Lois Tyson also explains deconstruction in relation to literature as follows:

Literature is as dynamic, ambiguous, and unstable as the language of which it is composed. Meaning is not a stable element residing in the text for us to uncover or passively consume. Meaning is created by the reader in the act of reading. Or more precisely, meaning is produced by the play of language through the vehicle of the reader. Furthermore, meaning that is created, is not a stable element capable of producing closure: that is, no interpretation has the final word. Rather, literary texts, like all texts, consist of a multiplicity of overlapping, conflicting meanings in dynamic, fluid relation to one another and to us. ${ }^{23}$

\section{FINDINGS}

1. Matt 6:12: The problem in Matt 6:12 is how the Greek words afes (forgive, let go) and ofeileemata (debts) have been rendered in the Dangme translation (BSG/UBS 1999). It was found out that among Dangme Bible

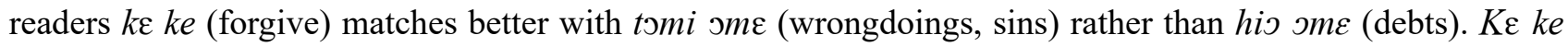
implies an outright gift; in this context, it connotes "letting go" of an offence by the one offended. This means that when one realizes that he or she has sinned against God and asks for forgiveness, God forgives; He "lets

\footnotetext{
19 Jonathan E. T. Kuwornu-Adjaottor, Mother-Tongue Biblical Hermeneutics: A Current Trend in Biblical Studies in Ghana. Journal of Emerging Trends in Educational Research and Policy Studies (JETERAPS) 3 no. 4 (2012): 575-579.

20 John D. K. Ekem. “Interpreting 'The Lord's Prayer' in the context of Ghanaian Mother Tongue Hermeneutics. “Journal of African Christian Thought 10 no. 2 (2007):48.

21 Ekem. Early Scriptures of the Gold Coast (Ghana), 10.

22 Jacques Derrida, Of Grammatology, (Baltimore: John Hopkins University Press, 1976); Jacques Derrida, "Structure, Sign and Play in the Discourse of Human Sciences," in Writing and Difference, trans. Alan Bass (Chicago: University of Chicago Press. 1978): $278-93$.

23 Lois Tyson, Critical Theory Today: A User-Friendly Guide (New York/London: Routledge, 2006), 258-259.
} 
go" the offence without keeping a record of it, or referring to it later. Similarly, those who say the Lord's Prayer (Matt 6:9-13) should "let go" the offences of those who wrong them if they want God to "let go" their wrongdoings. My suggested rendering of Matt 6:12 in the Dangme is Ne o kJ wa tomi ome ne ke wo (And let goour wrong-doings). This translation would help Dangme Bible readers to understand that forgiveness is about "letting go" the offence of an offender, without keeping any record of the offence.

2. Mark 1:12: The difficulty with Mark 1:12 in the Dangme Bible (BSG/UBS 1999) is the rendering of the Greek word ekballoo (cast out) as tse eyi se (push the head from behind). The study found out that ekballoo (cast out) connotes a strong action, and Jesus' usage of the word in expelling demons proves its forcefulness. The translators' rendering of ekballoo as tse eyi se (push the head from behind), an idiomatic expression, perhaps was so to tone down the forceful nature of ekballoo. This rendering has rather evolved varied interpretations by the Dangme Bible reading communities; notable among them being ha ne e ho (permitted him to go).

The author's suggested translation of Mark 1: 12 in Dangme as Mumi Klouklou ha ne e ho nga a no ya (The Holy Spirit permitted him to go to the wilderness), will clear the confusion in the minds of Dangme Bible readers who do not understand how the Holy Spirit could "push" Jesus into the wilderness. It will also help them to understand that when one is under the influence of the Holy Spirit, one is also under His control; the Holy Spirit permits one to do what pleases God. The Holy Spirit's activity understood this way would help determine when the Spirit or otherwise is working in the lives of people. This would be a check on the numerous charismatic experiences of people whose activities sometimes create doubt in the mind of people.

3. Luke 24:25: The rendering of anoeetoi (foolish) as kuasiahi (foolish people) in the Dangme Bible (BSG/UBS 1999 ) is a challenge to Dangme Bible readers in whose context, a priest does not use the word kuasia (fool) with respect to the living. It was found out that Jesus used anoeetoi as a rebuke and not an insult. His usage of anoeetoi on the two disciples on their way to Emmaus was to rebuke their unbelief in what the prophets have said about the Christ - that he would resurrect. Understood this way, one would have expected the Dangme translators to have used a rebuking word rather than an insult, coming from no mean a person as Jesus Christ. Alluding the use of kuasiahi to Jesus the divine, has lowered his respect among Dangme Bible readers.

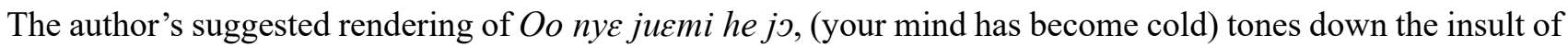
kuasiahi, making it a rebuke. This rendering reduces the degrading nature of kuasia which etymology means "a good for nothing person", "an unrespected person", "a worthless person." The rendering promotes the dignity of the human being who is wonderfully made in the image and likeness of God (Gen 1:26; Psalm 139: 13-14).

\section{CONCLUSION}

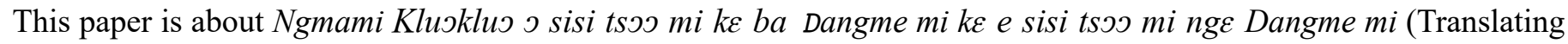
the Bible into Dangme and interpreting it in Dangme). Translation is not just a matter of finding equivalent words in two languages. It involves interpretation since it has the complicated task of transporting material from one world of thought and language to another. It is possible to study the mother tongue translations of the Bible academically. The Dangme Bible has grown beyond ordinary devotional reading. It has become an academic resource for study and interpretation. The Bible is one; but it must be read, understood and applied in the context of its readers. With the research the author has conducted on the Dangme Bible - its translation and interpretation - he has helped Dangme Bible readers to understand the Bible in the Dangme context.

\section{ABOUT AUTHOR}

Jonathan Edward Tetteh Kuwornu-Adjaottor (PhD) is an Associate Professor of New Testament and Mother Tongue Biblical Hermeneutics at the Department of Religious Studies, Kwame Nkrumah University of Science and Technology, Kumasi.

\section{BIBLIOGRAPHY}

Bediako, K. Christianity in Africa: The Renewal of Non-Western Religion. Maryknoll, New York: Orbis Books, 1999. . Jesus in Africa: The Gospel in African History and Experience. Akropong: Editions Clé and Regnum Africa, 2000.

. Biblical Exegesis in the African Context - The Factor and Impact of the Translated Scriptures" Journal of 
African Christian Thought Volume 6, Number 1, June 2003: 15-24.

. Religion, Culture and Language: An Appreciation of the Intellectual Legacy of Dr. J.B. Danquah - J. B.

Danquah Memorial Lectures, Series 37, February 2004. Accra: Ghana Academy of Arts \& Sciences, 2006.

Collins R. F. I \& II Timothy and Titus. The New Testament Library. Louisville: Westminster John Knox Press, 2002.

Derrida, J. Of Grammatology. Balttimore: John Hopkins University Press, 1976.

Ekem, J. D. K. Priesthood in Context: A Study of Priesthood in Some Christian and Primal Communities of Ghana and its Relevance for Mother-Tongue Biblical Interpretation. Accra: SonLife Press, 2008.

. Early Scriptures of the Gold Coast (Ghana): The Historical, Linguistic, and Theological Settings of the Gā, Twi, Mfantse, and Ewe Bibles. Rome/Manchester: Edizioni di Storia Eletteratura/St. Jerome, 2011.

Kpobi, D. N. A. Entrusted with the Word: A History of the Bible Society of Ghana, 1965-2015. Accra: Heritage Publications, 2015.

Kuwornu-Adjaottor, J. E. T. Mother-Tongue Biblical Hermeneutics: A Current Trend in Biblical Studies in Ghana. Journal of Emerging Trends in Educational Research and Policy Studies (JETERAPS) 3 no. 4 (2012): 575579.

. Doing Biblical Studies using the Mother-tongue Approach. All Nations University Journal of Applied Thought (ANUJAT) 1 no. 1 (2012): 55-80.

. A Comparative Study of the Translation of anoeetoi (Lk 24:25) in the Greek New Testament and Dangme Bible, in Samson Fatokun, Jacob Ayantayo Solomon.

Mepaiyeda, Olusesan Familusi, Samuel Okanlawon (eds) AFRICAN CHRISTIANITY IN LOCAL AND GLOBAL CONTEXT: A Festchrift in Honour of Rev. Prof Isaac Deji Ayegboyin. Ibadan: Department of Religious Studies, University of Ibadan, 2019: 232-243.

. A Critical Study of the Translation of Mark 1:12 in the Dangme Translation of the Bible. Oguaa Journal of Religion and Human Values 5 no 2 (2019):146-164.

. A Critical Translation of Matthew 6:12 in the Dangme Bible. Journal for the Study of the New Testament in Southern Africa 54 no. 1 (2020):67-86.

Sanneh, L. Translating the Message: The Missionary Impact on Culture. New York: Orbis Books, 2004.

. Gospel and Culture: Ramifying Effects of Scripture Translation. In: Stine, P.C. ed., Bible Translation and the Spread of the Church, The Last 200 Years. Leiden: Brill, 1990.

Tyson, L. Critical Theory: A User-Friendly Guide. New York/London: Routledge, 2006. 